\title{
Zoonosis in dogs and cats attended by the Birth Control Project: Toxoplasma gondii, Leishmania spp. and Leptospira spp., serodiagnosis and epidemiology
}

\section{Zoonoses em cães e gatos atendidos em Projeto de Controle de Natalidade: Toxoplasma gondii, Leishmania spp. e Leptospira spp., sorodiagnóstico e epidemiologia}

\author{
Eloiza Teles Caldart ${ }^{1 *}$; Caroline Constantino ${ }^{1}$; Aline Kuhn Sbruzzi Pasquali ${ }^{1}$; \\ Aline do Nascimento Benitez ${ }^{1}$; Fernando Nakanishi Hamada ${ }^{1}$; Renata Cristina \\ Ferreira Dias ${ }^{1}$; Andressa Maria Rorato-Nascimento ${ }^{1}$; Elizabete Regina Marangoni \\ Marana $^{4}$; Italmar Teodorico Navarro ${ }^{2}$; Nilva Maria Freres Mascarenhas ${ }^{3}$; \\ Julio Cesar de Freitas ${ }^{2}$; Roberta Lemos Freire ${ }^{2}$
}

\begin{abstract}
Increasing human-animal proximity has also increased risks of zoonotic disease transmission. This study measured the prevalence of anti-Toxoplasma gondii, anti-Leishmania spp. and anti-Leptospira spp. IgG antibodies in dogs and cats attended by the Birth Control Project (BCP) from 2004 to 2012 to determine which environmental variables were significantly associated with infectious agents in the study population. Blood samples from $271 \mathrm{dogs}$ and 415 cats were collected by jugular or cephalic venipuncture for serological analysis. Indirect immunofluorescence assays were used to detect anti- $T$. gondii and anti-Leishmania spp. IgG antibodies and microscopic serum-agglutination tests were used to detect anti-Leptospira spp. antibodies. Data tabulation and statistical analyses were performed using EpiInfo (3.4.3). Among canine sera samples, 20.6\% (56/271), 1.3\% (3/236), and 21.6\% (51/236) were positive for T. gondii, Leishmania spp., and Leptospira spp., respectively. Higher T. gondii prevalence was found in dogs of unknown breeding history $(\mathrm{p}=0.0009)$, those fed raw or undercooked meat $(\mathrm{p}=0.0101)$, and those that did not receive the polyvalent vaccine $(\mathrm{p}=0.0147)$. There was no statistically significant association between leishmaniosis and leptospirosis and variables evaluated in the epidemiological questionnaire. Among feline sera samples, 20.9\% (87/415) were positive for $T$. gondii. The highest prevalence rates were observed in felines that hunted rodents $(\mathrm{p}=0.0388)$ and that consumed untreated water $(p=0.0294)$. These results confirmed that ingestion of raw or undercooked meat, drinking untreated water, and predation of rodents were important risk factors for $T$. gondii infection. A low Leishmania spp. serodiagnostic prevalence was observed. The most frequent Leptospira spp. serovars were Copenhageni, Canicola, and Butembo.
\end{abstract}

Key words: Pets, population control, leishmaniasis, leptospirosis, toxoplasmosis

\footnotetext{
1 Discentes Dept ${ }^{\circ}$ de Medicina Veterinária Preventiva, Universidade Estadual de Londrina, UEL, Londrina, PR, Brasil. E-mail: eloiza.vet@gmail.com; caroline.const@hotmail.com; alinesbruzzi@gmail.com; aline.benitez@unifil.br; hashin82@gmail.com; rcfdias14@gmail.com; andressarorato@gmail.com

2 Profs. Drs., Dept ${ }^{\circ}$ de Medicina Veterinária Preventiva, UEL, Londrina, PR, Brasil. E-mail: italmar@uel.br; freitasj@uel.br; rlfreire@uel.br

3 Prof ${ }^{\mathrm{a}}, \mathrm{Dr}^{\mathrm{a}}$, Dept ${ }^{\mathrm{o}}$ de Clínicas Veterinárias, UEL, Londrina, PR, Brasil. E-mail: mascaren@uel.br

4 Técnico Laboratorial do Dept ${ }^{\mathrm{O}}$ de Medicina Veterinária Preventiva, UEL, Londrina, PR, Brasil. E-mail: ermarana@uel.br Author for correspondence
} 


\section{Resumo}

A proximidade da relação homem-animal tem aumentado o risco de transmissão de doenças de caráter zoonótico. O objetivo desse trabalho foi determinar a prevalência de anticorpos IgG anti-Toxoplasma gondii, anti-Leishmania spp. e anti- Leptospira spp. nos cães e gatos atendidos pelo Projeto Controle de Natalidade (PCN) nos anos de 2004 a 2012 e verificar a significância estatística de variáveis ambientais e da população de estudo à presença dos agentes infecciosos. Amostras de sangue de 271 cães e 415 gatos foram colhidas por venopunção jugular ou cefálica para a posterior obtenção dos soros. Estes foram submetidos à técnica de imunofluorescência indireta para detecção de anticorpos IgG anti- $T$. gondii e anti-Leishmania spp. e à técnica de soroaglutinação microscópica para detecção de anticorpos anti- Leptospira spp. A tabulação dos dados foi realizada utilizando-se o pacote estatístico EpiInfo (3.4.3). Dos soros caninos examinados, 20,6\% (56/271), 1,3\% (3/236) e 21,6\% (51/236) foram positivos para T. gondii, Leishmania spp. e Leptospira spp., respectivamente. Encontrou-se maior prevalência de anticorpos anti- $T$. gondii em cães sem raça definida ( $\mathrm{p}=0,0009)$, em cães alimentados com carne crua ou mal cozida $(p=0,0101)$ e naqueles que não receberam vacina polivalente $(p=0,0147)$. Não houve associação estatística entre as variáveis avaliadas no questionário epidemiológico para leishmaniose e leptospirose. Dos soros felinos analisados, 20,9\% (87/415) foram positivos para $T$. gondii. Maiores prevalências foram observadas nos felinos com hábito de caçar roedores $(\mathrm{p}=0,0388)$ e que não recebem água tratada $(\mathrm{p}=0,0294)$. Os resultados obtidos confirmam a importância dos fatores de risco ingestão de carne crua ou mal cozida, ingestão de água não tratada e predação de roedores para infecção por $T$. gondii. Demonstrou-se baixa prevalência ao sorodiagnostico para Leishmania spp. Os sorovares de Leptospira spp. mais frequentes foram Copenhageni, Canicola e Butembo.

Palavras-chave: Toxoplasmose, leptospirose, leishmaniose, animais de companhia, controle populacional

\section{Introduction}

Increasing acquisition of pets and closer humananimal relationships has increased the risk of zoonotic disease transmission, making it important to determine the prevalence of these diseases in animal populations.

Toxoplasma gondii is an obligate intracellular coccidia parasite with a facultative heteroxenous life cycle (TENTER et al., 2000). Toxoplasmosis is one of the most common parasitic zoonoses worldwide (DUBEY, 1993) and, according to Baneth et al. (1996), the parasite can infect all warmblooded animals. $T$. gondii has diverse transmission routes within and between host species. When initially contracted during pregnancy, $T$. gondii can be transmitted vertically by tachyzoites that pass through the placenta to the fetus. Horizontal transmission involves different parasite life stages such as ingestion of sporulated oocysts from the environment or tissue cysts in animal flesh or viscera (TENTER et al., 2000). However, the epidemiological importance of each of these routes depends on the population and environment. Because they inhabit the same environments, dogs and humans are similarly exposed to $T$. gondii; therefore, canine toxoplasmosis can be considered an epidemiological indicator of the risk of toxoplasmosis transmission to humans. Domestic and wild cats are the only hosts capable of shedding oocysts. According to Dubey et al. (2012), seropositivity rates from 25.0 to $50.0 \%$ among Brazil's approximately 12 million cats and consequent shedding of 1 million oocysts per positive cat suggests that this country has worrying high potential environmental contamination by oocysts. Bresciani et al. (2008) found serology to be a feasible, simple, and economically viable diagnostic method for measuring seroprevalence. Furthermore, the authors observed that indirect immunofluorescence assays (IFA) are most commonly used in toxoplasmosis epidemiological studies.

Leishmaniasis, affecting twenty million people globally (DUJARDIN et al., 2008), is caused by 
members of the genus Leishmania (Kinetoplastida: Trypanosomatidae), protozoa that infect multiple mammalian species and are transmitted by the bite of infected phlebotomine sandflies (GRAMICCIA, 2011). Leishmania braziliensis is the prevalent causative agent of American cutaneous leishmaniasis (ACL) in South America and occurs in every Brazilian state; autochthonous cases have been reported in the Vale do Ribeira, central, and northern regions of Paraná state (CASTRO et al., 2007). According to Dantas-Torres et al. (2010), there is still speculation concerning the role of dogs as important ACL reservoirs; however there is no doubt that dogs are good sentinels for disease distribution and that the primary reservoirs are small wild rodents. Serological methods including IFA and enzyme-linked immunosorbent assay (ELISA) are widely used for laboratory diagnosis, (GRADONI; GRAMICCIA, 2008).

Leptospirosis, caused by the spirochete Leptospira interrogans, is an important zoonosis that can affect mammalian species including dogs, rodents, cattle, sheep, goats, pigs, and horses. Leptospires can survive in humid environments such as soil, mud, groundwater, streams, and rivers. Humans and animals are infected by direct contact with infected animal urine, typically canines and rodents, or by indirect contact with water contaminated by these bacteria (MONAHAN et al., 2009). The disease has a worldwide distribution and can cause systemic infections with clinical presentations that vary according to host species and Leptospira spp. serovar (FAINE et al., 1999). Brod et al. (2005), reported dogs to be the main transmission reservoirs between humans and dogs in urban environments; therefore, vaccination of dogs is an important measure for leptospirosis prevention and control (DUNN, 2001). Rodents are permanent reservoirs of several Leptospira serovars, leading to constant environmental contamination by the pathogen. As a consequence, rodents are a perpetual source of infection for humans as well as other animal species (SANTAROSA et al., 1980). Leptospirosis antibodies are most commonly detected and Leptospirosis diagnosed by microscopic serum-agglutination tests (MAT) using live antigens.

The Birth Control Project (BCP) offered by the Veterinary Medicine Course at the Universidade Estadual de Londrina (UEL) offers low-cost surgical sterilization of pets and an opportunity for students to learn these techniques under instructor supervision. Considering the zoonotic potential of these etiologic agents, this study measured the antiToxoplasma gondii, anti-Leishmania spp., and antiLeptospira spp. IgG antibody prevalence in dogs and cats attended by the BCP at UEL from 2004 to 2012 and evaluated the statistical significance of environmental variables associated with infectious agents in the study population.

\section{Material and Methods}

This study was approved by the Ethics and Animal Experimentation Committee and obtained a favorable opinion $\left(n^{\circ} 60 / 08\right)$ for execution of the work.

\section{Area and study population}

The city of Londrina $\left(23^{\circ} 18^{\prime} 36^{\prime \prime} \mathrm{S} / 51^{\circ} 09^{\prime} 46^{\prime \prime} \mathrm{W}\right)$ is located in the northern region of Paraná State, a North-central mesoregion of Paraná in southern Brazil. It lies $610 \mathrm{~m}$ above sea level and has a subtropical climate, with year-round rainfall concentrated mostly during the summer months. It has an average annual temperature above $21^{\circ} \mathrm{C}$ and an estimated human population of 506,701 (IBGE, 2011). There are an estimated 127,677 dogs in the city (ZULPO et al., 2012).

\section{Animal sampling}

Between March 2004 and July 2012, blood samples were collected from $271 \mathrm{dogs}$ and 415 cats from the Birth Control Project of Universidade Estadual de Londrina and evaluated. 


\section{Serum collection}

Blood was collected by jugular or cephalic venipuncture and stored at room temperature in test tubes without anticoagulant until complete clot retraction. The blood clot was centrifuged for 10 min at $1,000 \mathrm{~g}$ to separate the serum.

\section{$I F A$}

Canine serum samples were analyzed by IFA to determine the prevalence of $\operatorname{IgG}$ anti-T. gondii and anti-Leishmania spp. antibodies according to Camargo (1974) and Oliveira et al. (2008), respectively. IFA was performed on serological samples from cats to determine the prevalence of IgG anti- $T$. gondii antibodies. T. gondii IFA slides were prepared with RH strain tachyzoites; samples with titers equal or higher than 16 were considered positive for toxoplasmosis. Leishmania spp. IFA slides were prepared using L. amazonensis promastigotes; samples with titers equal or higher than 40 were considered positive for leishmaniasis. Dog and cat anti-IgG conjugates (FITC - Sigma) were standardized for each reaction. Positive and negative controls were included in all slides tested. Samples considered positive were serially diluted four-fold and two-fold for T. gondii and Leishmania spp., respectively, until they were no longer positive.

\section{MAT}

Serological diagnosis was performed using MAT with 20 leptospirosis reference serovars: Australis, Autumnalis, Bratislava, Butembo, Bataviae, Canicola, Castellonis, Copenhageni, Cynopteri, Fortbragg, Grippotyphosa, Hardjo, Hebdomadis, Icterohaemorrhagiae, Panama, Pomona, Pyrogenis, Shermani, Whitcombi, and Wolffi. Some canine samples were not tested due to insufficient sample volume. Feline samples were not tested because cats are refractory to leptospirosis.

Antigen cultures were maintained at $28^{\circ} \mathrm{C}$ for 5 to 10 days in modified EMJH medium (DIFCO ${ }^{\circledR}$
- USA). Serum samples able to agglutinate at least $50.0 \%$ of leptospires starting from titer levels of 100 were considered positive for leptospirosis. The sera from positive animals were diluted twofold to determine the maximum positive dilution (FAINE et al., 1999). Serovars with the higher agglutination titers were considered the most likely match (VASCONCELLOS et al., 1997). Samples with co-agglutination at the highest dilutions were considered reactive only to Leptospira interrogans (ALMEIDA et al., 1994).

\section{Research tools}

Complete epidemiological questionnaires were obtained for $42.0 \%$ of dogs and $39.2 \%$ of cats and used for statistical analysis of variables including species, sex, breed, weight, age, origin, treated water consumption, raw meat or derivatives ingestion, hunting habits, presence of rodents in the house or neighborhood, sewage disposal, garbage disposal, existence of local residential waste areas, presence of garbage in the waste areas, rabies and polyvalent vaccine status, and existence of flooded areas around the residence.

\section{Statistical analysis}

Data tabulation was performed using Epi Info (3.4.3, CDC, Atlanta, GA, USA). Differences between proportions and statistical significance were evaluated by chi-square $\left(x^{2}\right)$ or Fisher's exact tests with a $5.0 \%$ significance level.

\section{Results}

The canine population was $51.5 \%$ female, $69.5 \%$ were of unknown breeding, $69.0 \%$ were between one and eight years of age, $90.3 \%$ were from urban areas, and $69.1 \%$ lived in a residence.

Of 271 dogs tested for anti-T. gondii antibodies, $56(20.6 \%)$ had titers between 16 and 4,096. Significantly higher toxoplasmosis prevalence was 
found in dogs of unknown breeding $(\mathrm{p}=0.0009)$, those fed raw or undercooked meat $(\mathrm{p}=0.0101)$, and those who had not received the polyvalent vaccine $(\mathrm{p}=0.0147)$.

Of 236 canine samples tested for anti-Leishmania spp. antibodies, three (1.2\%) had titers between 40 and 80. Among leishmaniasis-positive animals, three were of unknown breeding, were of medium size and two were male. Only one had a completed epidemiological questionnaire, which indicated the presence of a waste area close to the animal's residence. However, there was no statistical association between leishmaniasis and the variables evaluated in the epidemiological questionnaire.

Fifty-one of 236 animals (21.6\%) were considered positive for Leptospira spp. with titers between 100 and 12,800. The percentage of samples that reacted with a single serovar was $88.3 \%$ (45/51). The Copenhageni serovar was most prevalent, found in 9 of 45 samples (20.0\%), followed by Canicola and Butembo, detected in 8 samples each (17.8\%) (Tables 1 and 2 ). It was not possible to determine the most likely serovar in 6 of 51 samples $(11.7 \%)$ because they reacted with more than one serovar. The distribution of the most likely serovars by highest agglutinating titer and collection year are presented in Tables
1 and 2, respectively. No statistically significant association was found between leptospirosis and epidemiological questionnaire variables.

We found that 39 dogs (14.4\%) had antibodies against only the protozoan $T$. gondii, one $(0.4 \%)$ animal with antibodies against only Leishmania spp., and $36(15.2 \%)$ dogs with antibodies against only Leptospira spp. Finally, 178 dogs (65.7\%) were negative by serodiagnosis for toxoplamosis, leishmaniosis, and leptospirosis.

The feline population was $51.5 \%$ female, $85.3 \%$ were of unknown breeding, $49.8 \%$ were between one and eight years of age, 93.2\% were from urban areas, and $45.6 \%$ lived inside residences. Of 415 feline serum samples tested for anti-Toxoplasma gondii antibodies, 87 (20.9\%) had titers between 16 and 4,096. Higher prevalences were observed in felines who hunted rodents $(p=0.0388)$ and consumed untreated water $(\mathrm{p}=0.0294)$.

Table 3 shows T. gondii and Leishmania spp IFA antibody titers. It is important to note that a higher proportion of high IFA anti- $T$. gondii antibody titers (256 and 4,096) was found in cats compared to dogs. The annual prevalence of anti-T. gondii, anti-Leishmania spp. and anti-Leptospira spp. IgG antibodies are shown in Table 4.

Table 1. Results of the most likely serovars and antibody titers for Leptospira interrogans obtained by microscopic serum-agglutination test (MAT) performed in $236 \mathrm{dogs}$ from the Birth Control Program of Universidade Estadual de Londrina, Paraná from March 2004 to July 2012.

\begin{tabular}{cccccccccc}
\hline Titer & $\mathbf{1 0 0}$ & $\mathbf{2 0 0}$ & $\mathbf{4 0 0}$ & $\mathbf{8 0 0}$ & $\mathbf{1 6 0 0}$ & $\mathbf{3 2 0 0}$ & $\mathbf{6 4 0 0}$ & $\mathbf{1 2 8 0 0}$ & $\begin{array}{c}\text { Reactive } \\
\mathbf{( \% )}\end{array}$ \\
\hline Autumnalis & 1 & & 1 & & & & & & $2(4.4 \%)$ \\
Bratislava & 3 & & 1 & & & & & & $4(8.9 \%)$ \\
Butembo & 2 & 2 & 1 & 2 & 1 & & & & $8(17.8 \%)$ \\
Canicola & 3 & & 1 & & 2 & & 1 & 1 & $8(17.8 \%)$ \\
Copenhageni & 2 & 3 & 1 & 3 & & & & & $9(20.0 \%)$ \\
$\quad$ Hardjo & 3 & & & & & & & & $3(6.7 \%)$ \\
Hebdomadis & 1 & & & & & & & & $1(11.1 \%)$ \\
Icterohaemorrhagiae & 2 & & 1 & & & & & & $3(6.7 \%)$ \\
Pomona & 1 & & & & & & & & $1(11.1 \%)$ \\
Pyrogenes & 3 & & & & 1 & & 2 & & $6(13.3 \%)$ \\
\hline Reactive & 21 & 5 & 6 & 5 & 4 & 0 & 3 & 1 & 45 \\
(\%) & $(46.7 \%)$ & $(11.1 \%)$ & $(13.3 \%)$ & $(11.1 \%)$ & $(8.9 \%)$ & $(0.0 \%)$ & $(6.7 \%)$ & $(2.2 \%)$ & $(100.0 \%)$ \\
\hline
\end{tabular}


Table 2. Distribution of the results of the most likely Leptospira interrogans serovars according to the year in wich the analyzed serum was obtained from 236 dogs from the Birth Control program of Universidade Estadual de Londrina, Paraná, from March 2004 to July 2012.

\begin{tabular}{|c|c|c|c|c|c|c|c|c|c|}
\hline Titer & 2004 & 2005 & 2007 & 2008 & 2009 & 2010 & 2011 & 2012 & $\begin{array}{c}\text { Reactive } \\
(\%)\end{array}$ \\
\hline Autumnalis & & $1(6.3 \%)$ & & & $1(33.3 \%)$ & & & & $2(4.4 \%)$ \\
\hline Bratislava & $1(12.5 \%)$ & $1(6.3 \%)$ & $1(33.3 \%)$ & & $1(33.3 \%)$ & & & & $4(8.8 \%)$ \\
\hline Butembo & $3(37.5 \%)$ & $1(6.3 \%)$ & & $2(40.0 \%)$ & & $1(25.0 \%)$ & $1(25.0 \%)$ & & $8(17.7 \%)$ \\
\hline Canicola & & $4(25.0 \%)$ & & & & $2(50.0 \%)$ & $2(50.0 \%)$ & & $8(17.7 \%)$ \\
\hline Copenhageni & & $5(31.3 \%)$ & $1(33.3 \%)$ & $1(20.0 \%)$ & & & & $2(50.0 \%)$ & $9(20.0 \%)$ \\
\hline Hardjo & $2(25.0 \%)$ & $1(6.3 \%)$ & & & & & & & $3(6.7 \%)$ \\
\hline Hebdomadis & & & & & & & $1(25.0 \%)$ & & $1(2.2 \%)$ \\
\hline Icterohaemorrhagiae & & $1(6.3 \%)$ & & $1(20.0 \%)$ & $1(33.3 \%)$ & & & & $3(6.6 \%)$ \\
\hline Pomona & & & $1(33.3 \%)$ & $1(20.0 \%)$ & & & & & $2(4.4 \%)$ \\
\hline Pyrogenes & $2(25.0 \%)$ & $2(12.5 \%)$ & & & & $1(25.0 \%)$ & 2 & & $5(11.1 \%)$ \\
\hline Reactive & 8 & 16 & 3 & 5 & 3 & 4 & 4 & 2 & 45 \\
\hline$(\%)$ & $(17.7 \%)$ & $(35.5 \%)$ & $(6.6 \%)$ & $(11.1 \%)$ & $(6.6 \%)$ & $(8.8 \%)$ & $(8.8 \%)$ & $(4.4 \%)$ & $(100.0 \%)$ \\
\hline
\end{tabular}

Table 3. Number of positive animals concerning the final anti-IgG antibody titers for Toxoplasma gondii and Leishmania spp., obtained by indirect immunofluorescence assay in dogs and cats attended by the Birth Control Program of Universidade Estadual de Londrina, Paraná, from March 2004 to July 2012.

\begin{tabular}{lllllll}
\hline $\begin{array}{l}\text { Toxoplasma Titer } \\
(\mathbf{2 7 1} \text { canines) }\end{array}$ & $\mathbf{1 6}$ & $\mathbf{6 4}$ & $\mathbf{2 5 6}$ & $\mathbf{1 0 2 4}$ & $\mathbf{4 0 9 6}$ & Total \\
$\mathbf{N}(\%)=$ & $27(48.2 \%)$ & $18(32.1 \%)$ & $5(8.9 \%)$ & $4(7.1 \%)$ & $2(3.5 \%)$ & $56(100.0 \%)$ \\
\hline $\begin{array}{l}\text { Toxoplasma } \text { Titer } \\
(\mathbf{4 1 5 *} \text { felines) }\end{array}$ & $\mathbf{1 6}$ & $\mathbf{6 4}$ & $\mathbf{2 5 6}$ & $\mathbf{1 0 2 4}$ & $\mathbf{4 0 9 6}$ & Total \\
$\mathbf{N}(\%)=$ & $19(21,8 \%)$ & $17(19.5 \%)$ & $15(17.2 \%)$ & $22(25.3 \%)$ & $14(16.1 \%)$ & $87(100.0 \%)$ \\
\hline $\begin{array}{l}\text { Leishmania } \text { Titer } \\
(\mathbf{2 3 6 *} \text { canines) }\end{array}$ & $\mathbf{4 0}$ & $\mathbf{8 0}$ & $\mathbf{1 6 0}$ & $\mathbf{3 2 0}$ & $\mathbf{6 4 0}$ & Total \\
$\mathbf{N}(\%)=$ & $2(66.7 \%)$ & $1(33.3 \%)$ & $0(0.0 \%)$ & $0(0.0 \%)$ & $0(0.0 \%)$ & $3(100.0 \%)$ \\
\hline
\end{tabular}

* The number tested differ due to insufficient amount of sample.

Table 4. Seroprevalence of toxoplasmosis in dogs and cats and of leishmaniosis and leptospirosis in dogs attended by the Birth Control Program of Universidade Estadual de Londrina, Paraná, from March 2004 to July 2012.

\begin{tabular}{|c|c|c|c|c|c|c|c|c|}
\hline & \multicolumn{4}{|c|}{ Toxoplasma gondii } & \multirow{2}{*}{\multicolumn{2}{|c|}{$\begin{array}{c}\text { Leishmania spp. } \\
\text { canine }\end{array}$}} & \multirow{2}{*}{\multicolumn{2}{|c|}{$\begin{array}{c}\text { Leptospira spp. } \\
\text { canine }\end{array}$}} \\
\hline & \multicolumn{2}{|c|}{ canine } & \multicolumn{2}{|c|}{ feline } & & & & \\
\hline & $\mathbf{n} / \mathbf{N}$ & $(\%)$ & $\mathbf{n} / \mathbf{N}$ & $(\%)$ & $\mathbf{n} / \mathbf{N}$ & $(\%)$ & $\mathbf{n} / \mathbf{N}$ & $(\%)$ \\
\hline 2004 & $12 / 30$ & $(40.0 \%)$ & $30 / 83$ & $(36.1 \%)$ & $1 / 24$ & $(4.2 \%)$ & $11 / 24$ & $(45.8 \%)$ \\
\hline 2005 & $8 / 42$ & $(19.9 \%)$ & $10 / 59$ & $(16.9 \%)$ & $0 / 38$ & $(0.0 \%)$ & $17 / 38$ & $(44.7 \%)$ \\
\hline 2006 & $0 / 1$ & $(0.0 \%)$ & $0 / 4$ & $(0.0 \%)$ & $0 / 1$ & $(0.0 \%)$ & $0 / 1$ & $(0.0 \%)$ \\
\hline 2007 & $5 / 23$ & $(21.7 \%)$ & $7 / 57$ & $(12.3 \%)$ & $0 / 17$ & $(0.0 \%)$ & $3 / 17$ & $(17.6 \%)$ \\
\hline 2008 & $11 / 52$ & $(21.2 \%)$ & $15 / 81$ & $(18.5 \%)$ & $1 / 50$ & $(2.0 \%)$ & $5 / 50$ & $(10.0 \%)$ \\
\hline 2009 & $14 / 49$ & $(28.6 \%)$ & $11 / 49$ & $(22.4 \%)$ & $0 / 39$ & $(0.0 \%)$ & $4 / 39$ & $(10.3 \%)$ \\
\hline 2010 & $1 / 27$ & $(3.7 \%)$ & $1 / 23$ & $(4.3 \%)$ & $0 / 25$ & $(0.0 \%)$ & $5 / 25$ & $(20.0 \%)$ \\
\hline 2011 & $3 / 35$ & $(8.6 \%)$ & $10 / 38$ & $(26.3 \%)$ & $1 / 30$ & $(3.3 \%)$ & $4 / 30$ & $(13.3 \%)$ \\
\hline 2012 & $2 / 12$ & $(16.7 \%)$ & $3 / 21$ & $(14.3 \%)$ & $0 / 12$ & $(0.0 \%)$ & $2 / 12$ & $(16.7 \%)$ \\
\hline Total & $56 / 271$ & $(20.6 \%)$ & $87 / 415$ & $(20.9 \%)$ & $3 / 236$ & $(1.27 \%)$ & $51 / 236$ & $(21.6 \%)$ \\
\hline
\end{tabular}




\section{Discussion}

Dogs and humans sharing the same environment have similar $T$. gondii infection characteristics (MEIRELES, et al., 2004). Seroepidemiological studies of toxoplasmosis in dogs from rural and urban areas in the Paraná state show 20.8\% (5/24) to $84.1 \%(159 / 189)$ prevalence between 1992 and 2012. Freire et al. (1992) found a 75.9\% (193/254) prevalence and a higher percentage of infected adult dogs visiting the Veterinary Hospital (VH) at UEL. Garcia et al. (1999) studied dogs from rural properties in the city of Jaguapitã, in the same mesoregion as Londrina, and observed a $84.1 \%$ (159/189) positivity rate. Souza et al. (2003) reported a $34.4 \%(46 / 134)$ seropositivity rate in dogs from dairy farms in northern Paraná by MAT, in contrast to previous reports using IFA. Romanelli et al. (2007) observed a 20.8\% (5/24) prevalence in dogs from rural properties in south-central Paraná. Silva-Filho et al. (2012) performed a study in rural settlements of cities in northern Paraná, de Arapongas and Alvorada do Sul, and found an 82.2\% $(139 / 169)$ prevalence and statistically significant associations in cats aged $<1$ year living in the house and in adult dogs. A second study, conducted by Zulpo et al. (2012) with dogs that were patients at the UEL VH, showed that 50.9\% (57/112) were positive by IFA. The $20.6 \%$ prevalence found in this study is generally lower than reported by other studies in Paraná. Souza et al. (2003) studied two different dog populations in the city of São Paulo and reported a total prevalence of $19.7 \%(219 / 1110)$ : $5.2 \%(26 / 500)$ and 31.6\% (193/610) among house and stray dogs, respectively. In the present study, all dogs were domiciled, 90.3\% were from urban areas, and $69.1 \%$ lived inside houses, all factors that can reduce the risk of contact with environments contaminated by sporulated oocysts.

Dubey et al. (2012) suggested that the higher prevalence among stray dogs and those from rural environments could be due to predation. The results of this study confirm previous reports of raw or undercooked meat as a risk factor for $T$. gondii infection (TENTER et al., 2000). The absence of vaccination and unknown breed, also reported by Moura et al. (2009), do not directly affect the risk of infection; however these animals may belong to owners with lower purchasing power or with less health concerns regarding pets. Mineo et al. (2004) speculated that differences in prevalence could be associated with social standards, where owners with greater financial resources can buy better quality food (commercial diets) instead of feeding leftovers or scraps of raw meat.

Domestic cats are increasingly common in homes, especially apartments in urban Brazil (SERAFINI et al., 2008). Studies performed in Brazil have verified toxoplasmosis seroprevalence in different domestic cat populations. In Paraná, Garcia et al. (1999) reported a 73.0\% (119/163) prevalence among cats in a rural area. A study conducted by Dubey et al. (2004) of household felines in Santa Isabel do Ivaí, Paraná, the location of the largest outbreak of waterborne toxoplasmosis, revealed a prevalence of $84.4 \%$ (49/58) using MAT. Of these animals, 53 were subjected to a bioassay and $37(69.8 \%)$ were positive. In São Paulo state, 25.3\% (119/470) and $40.0 \%(80 / 200)$ prevalence were found among stray cats (SILVA et al., 2002; MEIRELES et al., 2004) and 17.7\% (44/248) and 19.4\% (37/191) among house cats (LUCAS et al., 1999; LANGONI et al., 2001 ), similar to the $20.9 \%$ prevalence in this study.

Domiciled cats with free access to the external environment have the opportunity to hunt small prey, making them more susceptible to $T$. gondii infection (ROBERTSON, 1998). Seropositivity rates in cats in this study were not significantly associated with their age. However, Cruz et al. (2011) reported a prevalence of $16.3 \%$ (46/282) among healthy house cats from veterinary clinics in Curitiba, Paraná, and found that seropositivity rates tended to increase with age, an observation also reported by Garcia et al. (1999). These findings are likely explained by increased exposure to different sources of infection and routes of transmission throughout their lives (LUCAS et al., 1999). 
Dubey et al. (2012) reported that carnivoreeating habits resulted in the majority of cats infected shortly after weaning; infections resulted in excretion of oocysts for 2 to 3 weeks and high oocyst burdens. Silva-Filho et al. (2012) found the presence of young cats to be associated with increased risk of $T$. gondii infection in humans, an observation that was not true for adult cats. The results from this study underscore the importance of well-known previously reported factors such hunting and consuming rodents and ingestion of untreated water (TENTER et al., 2000). Lucas et al. (1999) suggest that diets containing raw meat and access to the external environment are equally important factors in the occurrence of toxoplasmosis in cats. Therefore, feeding cats commercial diets and preventing them from hunting may reduce the prevalence of toxoplasmosis in the feline population.

Leishmaniases are dynamic diseases: transmission routes change based on environmental, demographic, and human behavioral factors that alter the range and density of vectors and reservoirs and increase the risk of human and animal exposure to infected phlebotomine sandflies (GRAMICCIA, 2011; DUJARDIN et al., 2008). Desjeux (2001) hypothesized that any environmental perturbation can cause changes in the distribution of parasites responsible for leishmaniasis. Studies performed by Silva et al. (2008) in the Paraná state and Oliveira et al. (2000) in Londrina, found abundant Lutzomyia whitmani, an important phlebotomine ACL vector. Luz et al. (2000) found L. whitmani naturally infected with $L$. braziliensis in the northern region of Paraná. Furthermore, Castro et al. (2001) reported that this vector easily adapts to houses and surroundings and is attracted to food, electric light, and abundant organic material.

ACL seroepidemiological studies in northern Paraná have shown prevalence to vary between $4.4 \%$ and $55.2 \%$ from 1996 to 2012 among dogs in rural and urban environments. Lonardoni et al. (2006) and Silva-Filho et al. (2012) reported $19.0 \%(24 / 126)$ and $8.3 \%(14 / 169)$ prevalence, respectively, among dogs in rural settlements in the cities of Mariluz, Alvorada do Sul, and Arapongas. Costa (2011) and Zulpo et al. (2012) studied animals from urban regions and the outskirts of Londrina and found 9.6\% (13/135) and 11.6\% (13/112) seropositivity, respectively. The animals studied by Costa (2011) lived in recycling sites and around urban forests. Castro et al. (2007) studied several cities in the northern part of the state, including Londrina, and observed a prevalence of $18.4 \%$ (39/212) using ELISA, in contrast to IFA used by the studies described above. Reis et al. (2011) evaluated urban dogs in Bela Vista do Paraíso, a city characterized by a considerably forested urban area, and found a prevalence of $45.4 \%$ (222/489) and $38.7 \%(189 / 489)$ by IFA and ELISA, respectively.

Besides northern Paraná, the central and Vale do Ribeira regions of Paraná state are also endemic for ACL. Castro et al. (2007) reported a 13.9\% (57/410) canine seropositivity rate in these three endemic regions. This study found no significant difference between environmental and health variables, likely because only three dogs $(1.27 \%)$ were seropositive. Because this study population consisted of clinically healthy animals undergoing elective castration surgery, the observed prevalence and antibody titers were easily obtained, which suggests that false negative results might contribute to the relatively low prevalence. Silva-Filho et al. (2012) observed a statistical association between prevalence and proximity of homes to the forest (up to $200 \mathrm{~m}$ ) in dogs from rural settlements.

Leptospirosis is a major zoonotic disease with a worldwide distribution; it has been described in a variety of warm-blooded vertebrates. Disordered urban growth promotes sanitation problems and a consequent proliferation of rodents, which are, together with dogs, the main carriers and reservoirs of leptospires in urban areas (GENOVEZ, 1996). Dogs play an important role in human leptospirosis epidemiology because of their proximity to humans (WEEKES et al., 1997), their status as reservoirs of serovar Canicola, and their ability to shed live 
leptospires in urine for several months (AVILA et al., 1998).

Several seroepidemiological studies have been performed in Londrina and nearby municipalities. Querino et al. (2003) found a prevalence of $25.0 \%$ (40/160) in serological samples from unvaccinated dogs with a clinical suspicion of infection at the UEL VH. Benitez et al. (2010) serologically evaluated stray dogs from the UEL campus and detected $21.2 \%$ prevalence (7/33). Benitez et al. (2012) also reported $20.2 \%$ prevalence $(132 / 653)$ in housedogs from the city of Jataizinho. These regional results generally agree with the findings of this study. The epidemiological variables evaluated in this study were not statistically significant compared to the serological results.

The most common serovars were Copenhageni (20.0\%), Canicola, and Butembo (17.8\% each), similar to a report by Mascolli et al. (2002) in dogs from Santana de Parnaíba that found 24.0\% Copenhageni and 20.0\% Canicola and Hardjo prevalence. Rats (Rattus norvegicus) are the main reservoir of the Copenhageni serovar (ELLISON; HILBINK, 1990). This serovar results in severe illness with jaundice; dogs that recover excrete leptospires in urine for variable amounts of time and can be sources of infection (VENKATARAMAN; NEDUNCHELLIYAN, 1993). The relatively high prevalence of serovar Copenhageni suggests a need for integrated rodent control programs that address rodent extermination and health education in addition to pest control (MASCOLLI et al., 2002).

Unlike this study, Benitez et al. (2010, 2012) found the Canicola serovar to be most common in Londrina and Jataizinho in Paraná, Magalhães et al. (2007) performed a study in Belo Horizonte, the capital of Minas Gerais state, and Araújo (2010) studied animals of rural origin in Aragominas, a city in Tocantins state. Rubel et al. (1997) found free street access to be the most important risk factor for canine leptospirosis, particularly serovar Canicola infections. Dogs are the main host of this serovar, which has adapted to renal tissue and generally causes a mild clinical presentation and shedding of leptospires in the urine for several months (MAGALHÃES et al., 2007); it is therefore important to reduce canine transmission of this serovar by preventing street exposure.

The Butembo serovar has reportedly lower prevalence in canines compared to this study (BLAZIUS et al., 2005; ARAÚJO, 2010). Wild animals have been identified as it natural hosts (SANTAROSA et al., 1980); however, it has also been reported in pigs and horses (FÁVERO et al., 2002).

The commercial canine leptospirosis vaccines most commonly administered by veterinarians contain bacterins from serovars Grippotyphosa, Pomona, Canicola, and Icterohaemorrhagiae (Vanguard $\left.{ }^{\circledR}\right)$. MAT does not distinguish between positive titers due to natural exposure and vaccination; however, Greene et al. (2006) reported positive titers lasted only three months after vaccination. The epidemiological questionnaire used in this survey included questions about administration of the polyvalent vaccine, but not the frequency or date of administration, an omission that prevented useful analysis.

\section{Conclusions}

More than $90.0 \%$ of the animals attended by the BCP are from urban areas of Londrina: nearly $70.0 \%$ of dogs and $45.0 \%$ of cats live inside their houses and have direct contact with their owners. Approximately $20.0 \%$ of the dogs and cats evaluated were seropositive for $T$. gondii. These results confirm that ingestion of raw or undercooked meat, drinking untreated water, and predation of rodents are significant risk factors for infection. Serodiagnosis showed low Leishmania spp. prevalence and no statistically significant variables were identified. The prevalence of anti-Leptospira spp. antibodies was $21.6 \%$ and the most abundant serovars were Copenhageni, Canicola, and Butembo. 


\section{Acknowledgements}

The authors thank the Pró-reitoria de Extensão (PROEX) of the Universidade Estadual de Londrina for their financial support of the Birth Control Project.

\section{References}

ALMEIDA, L. P.; MARTINS, L. F. da S.; BROD, C. S. Levantamento soroepidemiológico de leptospirose em trabalhadores do serviço de saneamento ambiental em localidade urbana da região sul do Brasil. Revista de Saúde Pública, São Paulo, v. 28, n. 1, p. 76-81, 1994.

ARAÚJO, B. M. Soroepidemiologia da infecção por Leptospira spp. em bovinos, equídeos, caninos e trabalhadores rurais em assentamento no município de Aragominas, Tocantins, Brasil. 2010. Tese (Doutorado em Ciência Animal), Universidade Federal de Goiás, Goiânia.

AVILA, M. O.; FURTADO, L. R. I.; TEIXEIRA, M. M.; ROSADO, R. L. I.; MARTINS, L. F. S.; BROD, C. S. Aglutininas anti-leptospíricas em cães na área de influência do Centro de Controle de Zoonoses, Pelotas, RS, Brasil, 1995. Ciência Rural, Santa Maria, v. 28, n. 1, p. 107-110, 1998.

BANETH, G.; SHKAP, V.; SAVITSKY, I. The prevalence of antibodies to Toxoplasma gondii in dogs in Israel. Israel Journal of Veterinary Medicine, Israel, v. 51, n. 1, p. 31- 33, 1996.

BENITEZ, A.; RODRIGUES, G. G.; GONÇALVES, D. D.; ALVES, L. A.; MÜLLER, E. E.; FREITAS, J. C. de. Leptospirose em cães errantes encontrados em campus universitário: avaliação sorológica e exame direto da urina. Semina: Ciências Agrárias, Londrina, v. 31, n. 1, p. 191-196, 2010.

BENITEZ, N. A. do; GONÇALVES, D. D.; FREIRE, R. L.; RODRIGUES, W. B.; SOUZA, V. R. A.; BARBARA, J. C. A.; FREITAS, J. C. de. Seroepidemiology of leptospirosis in pet dogs in the urban area of the municipality of Jataizinho, Paraná. Semina: Ciências Agrárias, Londrina, v. 33, p. 3201-3210, 2012. Suplemento 2.

BLAZIUS, R. D.; ROMÃO, P. R. T.; BLAZIUS, E. M. C. G.; SILVA, O. S. da. Ocorrência de cães errantes soropositivos para Leptospira spp. na cidade de Itapema, Santa Catarina, Brasil. Cadernos de Saúde Pública, Rio de Janeiro, v. 21, n. 6, p. 1952-1956, 2005.
BRESCIANI, K. D. S.; COSTA, A. J. da; NAVARRO, I. T.; TONIOLLO, G. H.; SAKAMOTO, C. A. M.; ANRANTES, T. P.; GENNARI, S. M. Toxoplasmose canina: aspectos clínicos e patológicos. Semina: Ciencias Agrárias, Londrina v. 29, n. 1, p. 189- 202, 2008.

BROD, C. S.; ALEIXO, J. A. G.; JOUGLARD, S. D. D.; FERNANDES, C. P. H.; TEIXIERA, J. L. R.; DELLAGOSTINS, A. Evidence of dog as a reservoir for human leptospirosis: a serovar isolation, molecular characterization and its use in a serological survey. Revista da Sociedade Brasileira de Medicina Tropical, Uberaba, v. 38, n. 4, p. 294-300, 2005.

CAMARGO, M. E. Introdução às técnicas de imunofluorescência. Revista Brasileira de Patologia Clínica, São Paulo, v. 10, n. 1, p. 143- 169, 1974.

CASTRO, E. A.; THOMAZ-SOCCOL, V.; AUGUIR, C. Standardization of ELIZA (Enzyme Linked Immunosorbent Assay) and Indirect Fluorescente Antibody Test (IFAT) techniques for canine cutaneous leishmaniasis. In: INTERNATIONAL CONFERENCE ON NEW HORIZONS IN BIOTECHNOLOGY, 1., 2001, Trivandrum. Abstracts... Trivandrum: IRD Editions, 2001. p. 228.

CASTRO, E. A.; THOMAZ-SOCCOL, V.; AUGUR, C. LUZ, E. Leishmania (Viannia) braziliensis: Epidemiology of canine cutaneous leishmaniasis in the State of Paraná (Brazil). Experimental Parasitology, v. 117, n. 1, p. 13-21, 2007.

COSTA, L. da. Ocorrência de anticorpos $\operatorname{Ig} G$ antiLeishmania spp. em cães de locais de reciclagem e nas adjacências de uma mata urbana de Londrina - PR. 2011. Dissertação (Mestrado em Ciência Animal) Universidade Estadual de Londrina, Londrina.

CRUZ, M. de, A.; ULLMANN, L. S.; MONTAÑO, P. Y.; HOFFMANN, J. L.; LANGONI, H.; BIONDO, A. W. Seroprevalence of Toxoplasma gondii infection in cats from Curitiba, Paraná, Brazil. Revista Brasileira de Parasitologia Veterinária, São Carlos, v. 20, n. 3, p. 256258, 2011.

DANTAS-TORRES, F.; PAIVA-CAVALCANTI, M. de; FIGUEREDO, L. A.; MELOB, M. F.; SILVA, F. J. da; SILVA, A. L. da; ALMEIDA, E. L.; BRANDÃO-FILHO, S. P. Cutaneous and visceral leishmaniosis in dogs from a rural community in northeastern Brazil. Veterinary Parasitology, Amsterdam, v. 170, n. 3-4, p. 313- 317, 2010.

DESJEUX, P. The increase in risk factors for leishmaniasis worldwide. Transactions of the Royal Society of Tropical Medicine and Hygiene, London, v. 95, n. 3, p. 239-243, 2001. 
DUBEY, J. P. Toxoplasma, Neospora, Sarcocystis and other tissue cyst- forming of human and animals. In: KRIER, J. P. Parasitic protozoa. San Diego: Academic Press, 1993. p. 1-157.

DUBEY, J. P.; LAGO, E. G.; GENNARI, S. M.; SU, C.; JONES, J. L. Toxoplasmosis in humans and animals in Brazil: high prevalence, high burden of disease, and epidemiology. Parasitology, Cambridge, v. 139, n. 1, p. 1-50, 2012.

DUBEY, J. P.; NAVARRO, I. T.; SREEKUMAR, C.; DAHLE.; FREIRE, R. L.; KAWABATA, H. H.; VIANNA, M. C. B.; KWOK, O. C. H.; SHEN, S. K.; THULLIEZ, P.; LEHMANN, T. Toxoplasma gondii infections in cats from Paraná, Brazil: seroprevalence, tissue distribution, and biologic and genetic characterization of isolates. The Journal of Parasitology, Lawrence, v. 90, n. 4, p. 721726, 2004.

DUJARDIN, J. C.; CAMPINO, L.; CAÑAVATE, C.; DEDET, J. P.; GRADONI, L.; SOTERIADOU, K.; MAZERIS, A.; OZBEL, Y.; BOELAERT, M. Spread of vector-borne diseases and neglect of leishmaniasis, Europe. Emerging Infectious Diseases, Atlanta, v. 14, n. 7, p. 1013-1018, 2008.

DUNN, J. K. Tratado de medicina de pequenos animais. São Paulo: Roca, 2001.

ELLISON, R. S.; HILBINK, F. Leptospiral infections in New Zeland dogs. Surveillance, v. 17, n. 2, p. 45-46, 1990.

FAINE, S.; ADLER, B.; BOLIN, C. Leptospira and leptospirosis. 2. ed. Melbourne: Medisci, 1999.

FÁVERO, A. C. M.; PINHEIRO, S. R.; VASCONCELLOS, S. A. MORAIS, Z. M.; FERREIRA, S.; FERREIRA-NETO, J. S. Most frequent serovars of leptospires in serological tests of buffaloes, sheeps, goats, horses, swines and dogs from several brazilian states. Ciência Rural, Santa Maria, v. 32, n. 4, p. 613-619, 2002.

FREIRE, R. L.; NAVARRO, I. T.; VIDOTTO, O.; TUDURY, E. A.; VIANNA, C. C. Prevalência de anticorpos anti-Toxoplasma gondii em cães atendidos no hospital veterinário da UEL-PR. Semina: Ciencias Agrárias, Londrina, v. 13, n. 1, p. 66-69, 1992.

GARCIA, J. L.; NAVARRO, I. T.; OGAWA, L.; OLIVEIRA, R.C.de. Soroepidemiologia da toxoplasmose em gatos e cães de propriedades rurais do município de Jaguapitã, Estado do Paraná, Brasil. Ciência Rural, Santa Maria, v. 29, n. 1, p. 99-104, 1999.

GENOVEZ, M. E. Leptospirose em cães. Pet Veterinária, v. 1, n. 1, p. 6-9, 1996.
GRADONI, L.; GRAMICCIA, M. Leishmaniosis. In: OIE manual of diagnostic tests and vaccines for terrestrial animals (mammals, birds and bees). Paris: Office International des Epizooties, 2008. v. 1, p. 240250.

GRAMICCIA, M. Recent advances in leishmaniosis in pet animals: epidemiology, diagnostics and anti-vectorial prophylaxis. Veterinary Parasitology, Amsterdam, v. 181, n. 1, p. 23-30, 2011.

GREENE, C. E.; SYKES, J. E.; BROWN, C. A. Leptospirosis. In: GREENE C. E. Infectious diseases of the dog and cat. Saint Louis: Saunders Elsevier, 2006. p. 402-417.

INSTITUTO BRASILEIRO DE GEOGRAFIA E ESTATÍSTICA - IBGE. IBGE cidades. São Paulo: IBGE, 2011. Disponível em: <http://www.ibge.gov.br/ cidadesat/topwindow.htm?1>. Acesso em: 22 mar. 2013.

LANGONI, H.; SILVA, A. V.; CABRAL, K. G.; CUNHA, E. L. P.; CUTOLO, A. A. Prevalência de toxoplasmose em gatos dos estados de São Paulo e Paraná. Brazilian Journal of Veterinary Research and Animal Science, São Paulo, v. 38, n. 5, p. 243-244, 2001.

LONARDONI, M. V. C.; SILVEIRA, T. G. V.; ALVES, W. A.; MAIA-ELKHOURY, A. N. S.; MEMBRIVE, U. A.; MEMBRIVE, N. A.; RODRIGUES, G.; REIS, N.; ZANZARINI, P. D.; ISHIKAWA, E.; TEODORO, U. Human and canine American cutaneous leishmaniasis in Mariluz, Paraná State, Brazil. Cadernos de Saúde Pública, Rio de Janeiro, v. 22, n. 12, p. 2713-2716, 2006.

LUCAS, S. R.; HAGIWARA, M. K.; LOUREIRO, V.; IKESAKI, J. Y. H.; BIRGEL, E. H. Toxoplasma gondii infection in Brazilian domestic outpatient cats. Revista do Instituto de Medicina Tropical de São Paulo, São Paulo, v. 41, n. 4, p. 221-224, 1999.

LUZ, E.; MEMBRIVE, N.; CASTRO, E. A.; DEREURE, J.; PRATLONG, F.; DEDET, J. A.; PANDEY, A.; THOMAZ-SOCCOL, V. Lutzomyia whitmani (Diptera: Psychodidae) as vector of Leishmania (V.) braziliensis in Paraná State, Southern Brazil. Annals of Tropical Medicine and Parasitology, United Kingdon, v. 94, n. 6, p. 623-631, 2000.

MAGALHÃES, D. F.; SILVA, J. A.; MOREIRA, E. C.; WILKE, V. M. L.; NUNES, A. B. V.; HADDAD, J. P. A.; MENESES, J. N. C. Perfil dos cães sororreagentes para aglutininas anti-Leptospira interrogans em Belo Horizonte, Minas Gerais, 2001/2002. Arquivo Brasileiro de Medicina Veterinária e Zootecnia, Belo Horizonte, v. 59, n. 5, p. 1326-1329, 2007. 
MASCOLLI, R.; PINHEIRO, S. R.; VASCONCELLOS, S. A.; FERREIRA, F.; MORAIS, Z. M.; PINTO, C. O.; SUCUPIRA, M. C. A.; DIAS, R. A.; MIRAGLIA, F.; CORTEZ, A.; COSTA, S. S. da; TABATA, R.; MARCONDES, A. G. Inquérito sorológico para leptospirose em cães do município de Santana do Parnaíba, São Paulo, utilizando a campanha de vacinação anti-rábica do ano de 1999. Arquivos do Instituto Biológico, São Paulo, v. 69, n. 2, p. 25-32, 2002.

MEIRELES, L. R.; GALISTEO JÚNIOR, A. J.; POMPEU, E.; ANDRADE-JUNIOR, H. F. Toxoplasma gondii spreading in an urban area evaluated by soroprevalence in free-living cats and dogs. Tropical Medicine and International Health, Spain, v. 9, n. 8, p. 878- 888, 2004.

MINEO, T. W. P.; SILVA, D. A. O.; NÄSLUND, K.; BJÖRKMAN, C.; UGGLA, A.; MINEO, J. R. Toxoplasma gondii and Neospora caninum serological status of different canine populations from Uberlândia, Minas Gerais. Arquivo Brasileiro de Medicina Veterinária e Zootecnia, Belo Horizonte, v. 56, n. 3, p. 414-417, 2004.

MONAHAN, A. M.; MILLER, I. S.; NALLY, J. E. Leptospirosis: risks during recreational activities. Journal of Applied Microbiology, v. 107, n. 3, p. 707-716, 2009.

MOURA, A. B. de; SOUZA, A. P. de; SARTOR, A. A.; BELLATO, V.; TEIXEIRA, E. B.; PISETTA, G. M.; HEUSSER-JUNIOR, A. Ocorrência de anticorpos e fatores de risco para infecção por Toxoplasma gondii em cães, nas cidades de Lages e Balneário Camboriú, Santa Catarina, Brasil. Revista Brasileira de Parasitologia Veterinária, São Carlos, v. 18, n. 3, p. 52-56, 2009.

OLIVEIRA, F. J. de A.; COSTA, I. C.; THOMAZ, M. E. B. Leishmaniose Tegumentar Americana: flebotomíneos de área de transmissão do Parque Arthur Thomas na região de Londrina - PR. Biosaúde, Londrina, v. 2, n. 2, p. 81-87, 2000.

OLIVEIRA, T. M. F. de S.; FURUTA, P. I.; CARVALHO, D. de; MACHADO, R. Z. A study of cross reactivity in serum samples from dogs positive for Leishmania sp.; Babesia canis and Ehrlichia canis in enzyme-linked immunosorbent assay and indirect fluorescent antibody test. Revista Brasileira de Parasitologia Veterinária, São Carlos, v. 17, n. 1, p. 7-11, 2008.

QUERINO, A. M. V.; DELBEM, A. C. B.; OLIVEIRA, R. C.; SILVA, F. G. da; MÜLLER, E. E.; FREIRE, R. L.; FREITAS, J. C. de. Fatores de risco associados à leptospirose em cães do município de Londrina - PR. Semina: Ciências Agrárias, Londrina, v. 24, n. 1, p. $27-$ 34, 2003.
REIS, H. R.; LOPES-MORI, M. R.; REIS, C. R.; FREIRE, R. L.; MARANA, E. R. M.; CHRYSSAFIDIS, A. L.; TEDIM, A. V.; RUFFOLO, B. B.; BUGNI, F. M.; CASTRO, E. A. de; THOMAZ-SOCCOL, V. NABUT, L. B.; NAVARRO, I. T. Soroprevalência da Leishmaniose Tegumentar Americana (LTA) canina e fauna de flebotomíneos (Diptera: Psychodidae) em Bela Vista do Paraíso, Paraná. Semina: Ciências Agrárias, Londrina, v. 32, n. 3, p. 1083-1094, 2011.

ROBERTSON, I. D. Survey of predation by domestic cats. Australian Veterinary Journal, Australia, v. 76, n. 4, p. 551-554, 1998.

ROMANELLI, P. R.; FREIRE, R. L.; VIDOTTO, O.; MARANA, E. R. M.; OGAWA, L.; PAULA, V. S. O. de; GARCIA, J. L.; NAVARRO, I. T. Prevalence of Neospora caninum and Toxoplasma gondii in sheep and dogs from Guarapuava farms, Parana State, Brazil. Research in Veterinary Science, Oxford, v. 82, n. 2, p. 202-207, 2007.

RUBEL, D.; SEIJO, A.; CERNIGOI, B. Leptospira interrogans en una población canina del Gran Buenos Aires: variables asociadas con la seropositividad. Revista Panamericana Salud Publica, local, v. 2, n. 2, p. 102106, 1997.

SANTAROSA, C. A.; SULZER, C. R.; YANAGUITA, R. M. Leptospirosis in wildlife in Brazil: isolation of serovars canicola, pyrogenes and grippotyphosa. International Journal of Zoonoses, v. 7, n. 1, p. 40-43, 1980.

SERAFINI, C. A.; ROSA, G. A.; GUIMARAES, A. M. S. Survey of owned feline and canine populations in apartments from a neighbourhood in Curitiba, Brazil. Zoonoses and Public Health, Oxford, v. 55, n. 8-10, p. 402-405, 2008.

SILVA, A. M. da; CAMARGO, N. J. de; SANTOS, D. R. dos. Diversidade, distribuição e abundancia de flebotomíneos (Diptera: Psychodidae) no Paraná. Neotropical Entomology, Switzerland, v. 37, n. 2, p. 209225,2008 .

SILVA, J. C.; GENNARI, S. M.; RAGOZO, A. M.; AMAJONES, V. R.; MAGNABOSCO, C.; YAI, L. E. O.; FERREIRA-NETO, J. S.; DUBEY, J. P. Prevalence of Toxoplasma gondii antibodies in sera of domestic cats from Guarulhos and São Paulo, Brazil. Journal of Parasitology, Lawrence, v. 88, n. 2, p. 419-420, 2002.

SILVA-FILHO, M. de F.; TAMEKUNI, K.; TOLEDO, R. dos S.; DIAS, R. C. F.; LOPES-MORI, F. M. R.; MITSUKA-BREGANÓ, R.; THOMAZ-SOCCOL, V.; GARCIA, J. L.; FREIRE, R L.; VIDOTTO, O.; NAVARRO, I. Infection by Toxoplasma gondii and Leishmania spp. in humans and dogs from rural 
settlements in Northern Paraná State, Brazil. Semina: Ciencias Agrárias, Londrina, v. 33, p. 3251-3264, 2012. Suplemento 2 .

SOUZA, S. L. P.; GENNARI, S. M.; YAI, L. E. O.; D'AURIA, S. R. N.; CARDOSO, S. M. S.; GUIMARÃES-JUNIOR, J. S.; DUBEY, J. P. Occurrence of Toxoplasma gondii antibodies in sera from dogs of the urban and rural areas from Brazil. Revista Brasileira de Parasitologia Veterinária, São Carlos, v. 12, n. 1, p. 1-3, 2003.

TENTER, A. M.; HECKEROTH, A. R.; WEISS, L. M. T. Toxoplasma gondii: from animals to humans. International Journal for Parasitology, v. 30, n. 12-13, p. 1217-1258, 2000.

VASCONCELLOS, S. A.; BARBARINI JR, O.; UMEHARA, O.; MORAIS, Z. M.; CORTEZ, A.; PINHEIRO, S. R.; FEREIRA NETO, J. S. Leptospirose bovina. Níveis de ocorrência e sorotipos predominantes em rebanhos dos Estados de Minas Gerais, São Paulo, Rio de Janeiro, Paraná, Rio Grande do Sul e Mato Grosso do Sul. Período de janeiro a abril de 1996. Arquivos do Instituto Biológico, São Paulo, v. 64, n. 2, p. 7-15, 1997.
VENKATARAMAN, K. S.; NEDUNCHELLIYAN, S. Soroepidemiology of canine leptospirosis in Madras city. Indian Journal of Animal Science, Indian, v. 63, n. 2, p. 150-152, 1993.

WEEKES, C. C.; EVERARD, C. O. R.; LEVETT, P. N. Seroepidemiology of canine leptospirosis on the island of Barbados. Veterinary Microbiology, Amsterdam, v. 51, n. 2, p. 215-212, 1997.

ZULPO, D. L.; LEITE, J. H. A. de C.; CUNHA, I. A. L. da. Ocorrência de anticorpos contra Leishmania spp., Neospora caninum e Toxoplasma gondii em soros de cães atendidos no Hospital Veterinário da Universidade Estadual de Londrina - PR. Semina: Ciências Agrárias, Londrina, v. 33, n. 5, p. 1897-1906, 2012. 
